\title{
PŘEDMLUVA: INTEGRAČNÍ PRÁVO
}

Právnická fakulta Univerzity Karlovy se již přes deset let intenzivně věnuje právním aspektům menšinové problematiky. Komplikované téma právního postavení menšin dřive vyvolávalo (kromě specifických výjimek typu prezidentských dekretů) až překvapivě malý zájem v české právní vědě, přestože je problematika menšin obecně populární mezi badateli společenských věd. Organizační úlohu v těchto výzkumných aktivitách na Právnické fakultě Univerzity Karlovy hraje zejména Ústav právních dějin, jehož ředitel prof. Jan Kuklík je již řadu let také děkanem. Při těchto aktivitách samozřejmě spolupracuje s mnoha dalšími českými i zahraničními odborníky zejména ze střední Evropy. Výrazný zájem je věnován především historii a dlouhodobému vývoji, ale i aktuální problémy jsou odborně zkoumány.

Na Právnické fakultě Univerzity Karlovy již více než desetiletí působí tým odborníků věnující se otázce právního postavení menšin spolupracující i s badateli z jiných institucí. K nejdůležitějším výsledkům patř́ knihy Petráš - Petrův - Scheu a kol.: Menšiny a právo v České republice (Praha: Auditorium, 2009), Petráš a kol.: Aktuální problémy právního postavení menšin v České republice (Praha: Úřad vlády, 2010), Scheu a kol.: Migrace a kulturni konflikty (Praha: Auditorium, 2011), Scheu - Kříž - Děkanovská a kol.: Právní postavení náboženských menšin (Praha: Univerzita Karlova, Právnická fakulta, 2013). Početné jsou hlavně historické publikace jako Petráš: Menšiny v komunistickém Československu (Praha: VIP, 2007), Petráš: Menšiny v meziválečném Československu (Praha: Karolinum, 2009), Petrův (Hofmannová): Zákonné bezpráví: Židé v Protektorátu Čechy a Morava (Praha: Auditorium, 2011), Petráš: Cizinci ve vlastní zemi: Menšinové konflikty v moderní Evropě (Praha: Auditorium, 2012), Kuklík - Němeček: Od národního státu ke státu národností? (Praha: Karolinum, 2013), Kuklík a kol.: Jak odškodnit holocaust (Praha: Karolinum, 2015), Kuklík - Petráš: Minorities and Law in Czechoslovakia 1918-1992 (Praha: Karolinum, 2017).

K důležitým výsledkům výzkumu právního postavení menšin patří i speciální čísla domácích i zahraničních časopisů (např. Acta Humana, 2015, No. 4). Klíčovou roli hraje tradiční univerzitní vědecký časopis Acta Universitatis Carolinae Iuridica, ve kterém tedy tímto vychází již čtvrté monotematické menšinové číslo. Jako 1/2013 vyšlo v časopise AUC Iuridica monotematické číslo věnované různým aspektům právního postavení menšin v širokém interdisciplinárním záběru. Na přelomu let 2015 a 2016 
vyšla navazující čísla 4/2015 a 1/2016. Číslo 4/2015 zpracovalo právní úpravu a praxi užívání menšinových jazyků spolu s právním postavením mateřských států v systému ochrany národnostních menšin. Č́slo 1/2016 prozkoumalo otázky náboženských menšin a náboženských symbolů, ale i další speciální problémy právního postavení menšin. Velkou praktickou výhodou časopisu, v české právní vědě dosud neobvyklou, je jeho okamžitá publikace jak tištěná, tak elektronická (navíc volně př́stupná).

Toto číslo časopisu Acta Universitatis Carolinae Iuridica představuje problém postavení menšin v kontextu současné migrace př́islušníků etnicky a kulturně odlišných komunit do Evropy. Integrační právo je komplexní a rychle se vyvíjející právní oblast, která zahrnuje relevantní normy ústavního práva, rodinného práva, sociálního práva, trestního práva, správního práva a dalších právních disciplín. Během procesu začleňování přistěhovalcủ do společenství hraje klíčovou roli mezinárodní i evropský standard ochrany lidských práv včetně práv menšin.

Číslo je rozčleněno logicky na dva základní okruhy, kdy v prvním jsou př́spěvky věnované právním otázkám integrace $\mathrm{v}$ ČR, ve druhém jsou představeny zahraniční zkušenosti. Čeští i zahraniční odborníci se zde zabývají různými aspekty integrace, od ústavních koncepcí, norem upravujících naturalizaci cizinců až po otázky sociálního a pracovněprávního začlenění. Cílem autorského kolektivu je poprvé v českém kontextu představit integrační právo jako novou právní oblast, která je úzce propojena s menšinovou problematikou a úpravou migrace. Věříme, že na tuto první vlaštovku budou navazovat další odborné studie, které budou přispívat $\mathrm{k}$ deideologizaci a racionálnímu řešení politicky výjimečně citlivé otázky ve světle stávajících právních závazků.

Články jsou (pokud není uvedeno jinak) výsledkem projektu Univerzity Karlovy Progres Q05 Právní a společenské aspekty migrace a problémy postavení menšin - koordinátor prof. JUDr. Jan Kuklík, DrSc. 